\title{
The Arc of synaptic memory
}

\author{
Clive R. Bramham • Maria N. Alme • Margarethe Bittins · Sjoukje D. Kuipers • \\ Rajeevkumar R. Nair · Balagopal Pai · Debabrata Panja · Manja Schubert • \\ Jonathan Soule $\cdot$ Adrian Tiron $\cdot$ Karin Wibrand
}

Received: 11 June 2009 / Accepted: 18 July 2009 / Published online: 19 August 2009

(C) The Author(s) 2009. This article is published with open access at Springerlink.com

\begin{abstract}
The immediate early gene $\operatorname{Arc}$ is emerging as a versatile, finely tuned system capable of coupling changes in neuronal activity patterns to synaptic plasticity, thereby optimizing information storage in the nervous system. Here, we attempt to overview the Arc system spanning from transcriptional regulation of the Arc gene, to dendritic transport, metabolism, and translation of Arc mRNA, to post-translational modification, localization, and degradation of Arc protein. Within this framework we discuss the function of Arc in regulation of actin cytoskeletal dynamics underlying consolidation of long-term potentiation (LTP) and regulation of AMPA-type glutamate receptor endocytosis underlying long-term depression (LTD) and homeostatic plasticity. Behaviorally, Arc has a key role in consolidation of explicit and implicit forms of memory, with recent work implicating Arc in adaptation to stress as well as maladaptive plasticity connected to drug addiction. Arc holds considerable promise as a "master regulator" of protein synthesis-dependent forms of synaptic plasticity, but the mechanisms that modulate and switch Arc function are only beginning to be elucidated.
\end{abstract}

Keywords Synaptic plasticity - LTP/LTD . Gene expression · Memory $\cdot$ Stress $\cdot$ Drug addiction · Neurogenesis $\cdot$ RNA decay

C. R. Bramham $(\bowtie) \cdot$ M. N. Alme · M. Bittins · S. D. Kuipers · R. R. Nair · B. Pai - D. Panja · M. Schubert - J. Soule · A. Tiron · K. Wibrand

Department of Biomedicine and Bergen Mental Health Research Center, University of Bergen, Jonas Lies vei 91, 5009 Bergen, Norway

e-mail: clive.bramham@biomed.uib.no

\section{Introduction}

The brain extracts information about the world that shapes our behavior and ultimately influences who we are as individuals. The immense capacity and specificity of memory storage in the mammalian central nervous system is thought to depend on the modifiability or plasticity of synaptic connections. Dysfunction of synaptic plasticity is implicated in a range of disorders from Alzheimer's disease to mental retardation and development of chronic pain states. Understanding how neural activity patterns are translated into lasting changes in synaptic connectivity is therefore one of the most important challenges in basic and clinical neuroscience (Bliss et al. 2007; Citri and Malenka 2008; Nelson and Turrigiano 2008).

Glutamatergic synapses are capable of expressing diverse forms of plasticity in response to synaptic input, including several mechanistically distinct kinds of synaptic strengthening (potentiation), weakening (depression), and homeostatic synaptic scaling. Key to current thinking is the requirement for new gene expression and protein synthesis in the development of enduring synaptic modifications and long-term changes in behavior, probably involving orchestrated synthesis and degradation of hundreds of proteins (Lee et al. 2005; Park et al. 2006; Wibrand et al. 2006; Havik et al. 2007; Liao et al. 2007).

The dendritic tree of a typical projection neuron in the adult mammalian brain contains some 10,000 dendritic spines onto each of which a single excitatory, glutamatergic synapse is formed. As a discrete structural, physiological, and biochemical compartment, dendritic spines offer a necessary degree of synaptic autonomy for information processing and storage. But, since gene expression occurs in the nucleus, how does activation of a small set of synapses lead to protein synthesis-dependent modification of those synapses? One attractive mechanism for this, as originally 
conceived by Oswald Steward and colleagues, is dendritic protein synthesis (Steward and Levy 1982; Steward and Reeves 1988; Steward and Schuman 2003; Bramham and Wells 2007). Through activity-dependent local synthesis and degradation of proteins, synaptic inputs may directly remodel the protein composition, and thereby the functional state, of individual dendritic spines or spine neighborhoods.

This review highlights the special functional relevance of the immediate early gene (IEG) Arc/Arg3.1 (activityregulated cytoskeleton-associated protein/activity-regulated gene 3.1), for simplicity henceforth referred to as Arc. The discovery of Arc was independently reported by the laboratories of Dietmar Kuhl and Paul Worley in 1995 (Link et al. 1995; Lyford et al. 1995). Uniquely, Arc mRNA is induced by synaptic activity and trafficked rapidly to dendrites where the RNA accumulates at sites of synaptic activity and undergoes local translation (Link et al. 1995; Lyford et al. 1995; Steward et al. 1998; Yin et al. 2002; Moga et al. 2004; Rodriguez et al. 2005). The implications from the original discovery of Arc have now been borne out in studies establishing a function for the protein in multiple forms of protein synthesis-dependent synaptic plasticity, including LTP elicited by high-frequency afferent stimulation (HFS) or infusion of brain-derived neurotrophic factor (BDNF), and LTD mediated by activation of group 1 metabotropic glutamate receptors (mGluRs). Various aspects of Arc have been discussed in focused reviews and commentaries (Tzingounis and Nicoll 2006; Castillo et al. 2008; Kubik et al. 2007; Bramham et al. 2008). Here, we attempt to overview the Arc system spanning from regulation of $\operatorname{Arc}$ RNA and protein, to functions in synaptic plasticity and adaptive behavior such as memory storage, and maladaptive behavior such as drug addiction.

\section{Transcriptional regulation of Arc}

Arc mRNA is rapidly expressed in principal neurons of rodent forebrain following seizures, learning experience, and following induction of LTP by HFS or BDNF (Link et al. 1995; Lyford et al. 1995; Steward et al. 1998; Waltereit et al. 2001; Ying et al. 2002; Kubik et al. 2007). However, the signal-transduction cascades that connect synaptic activity to transcription in the nucleus are not fully understood. Activation of $N$-methyl-D aspartate receptor (NMDAR) type glutamate receptors and extracellular signal-regulated kinase (ERK) are necessary for Arc transcription following LTP induction (Steward et al. 1998; Steward and Worley 2001; Panja et al. 2008) and in response to neuronal activity in primary hippocampal or cortical neuronal cultures (Rao et al. 2006). Arc is also induced pharmacologically in hippocampal neurons by BDNF, application of the group $1 \mathrm{mGluR}$ agonist dihydroxyphenylglycine (DHPG), or activation of adenylate cyclase by forskolin (Waltereit et al. 2001; Alder et al. 2003; Rao et al. 2006; Yasuda et al. 2007; Wang et al. 2009). Elevation of intracellular calcium and cAMP levels induces Arc in pheochromocytoma 12 cells and hippocampal neurons in a manner dependent on protein kinase A (PKA) and ERK activation (Waltereit et al. 2001). In SH-SY5Y neuroblastoma cells, muscarinic acetylcholine receptor agonists enhance $A r c$ expression via the cytoplasmic tyrosine kinase Src and protein kinase C (PKC), both of which are upstream of ERK (Teber et al. 2004). Interestingly, AMPA-type glutamate receptors downregulate $A r c$ gene expression in hippocampal neurons and organotypic hippocampal slice cultures through a pertussis toxin-sensitive G protein (Rao et al. 2006), suggesting that active neuronal networks are subject to negative feedback at the level of Arc transcription. While ERK appears to have a coordinating function, further work on the cross-talk between ERK, PKA, and PKC signaling is likely to be important for understanding the context-specific regulation of Arc transcription (Fig. 1).

Recent work has identified response elements in the Arc promoter underlying its activity-dependent transcriptional regulation. Waltereit et al. (2001) originally identified two serum response elements (SRE) at approximately $\sim 0.9 \mathrm{~kb}$ and $\sim 1.5 \mathrm{~kb}$ upstream of the transcription initiation site, but these elements were dispensable for transcriptional activation by calcium and cyclic AMP. Using a DNase I hypersensitivity assay to screen endogenous chromatin for important transcriptional regulatory regions, Pintchovski et al. (2009) identified two new enhancer elements located $\sim 6.5 \mathrm{~kb}$ and $\sim 1.4 \mathrm{~kb}$ upstream of the $A r c$ transcription startsite. The distal enhancer has a highly conserved SRE that binds serum response factor (SRF) and is recruited by synaptic activity, forskolin and BDNF. The proximal site contains a conserved "Zeste-like" element that enhances Arc induction by synaptic activity and BDNF application (Pintchovski et al. 2009). Interestingly, the Arc promoter also holds a unique activity-sensor named the synaptic activity-responsive element (SARE) which is $\sim 100 \mathrm{bp}$ in size and located at $\sim 7 \mathrm{~kb}$ upstream of the Arc transcription initiation site (Kawashima et al. 2009). Consisting of a unique cluster of binding sites for CREB, SRF, and myocyte enhancer factor-2 (MEF2) protein, the SARE is necessary for $A r c$ transcription and sufficient to confer rapid, synaptic activity-induced $A r c$ expression in hippocampal neurons. The SARE is also responsive to experience in live animals, as demonstrated by enhanced expression of a GFP-tagged SARE reporter in neurons of the primary visual cortex in mice that were exposed to light following a period of dark-rearing. Altogether, a set of elements have been identified within the 7-kb region of the Arc promoter which collectively recapitulate most of the known features of Arc transcription (Fig. 1). 


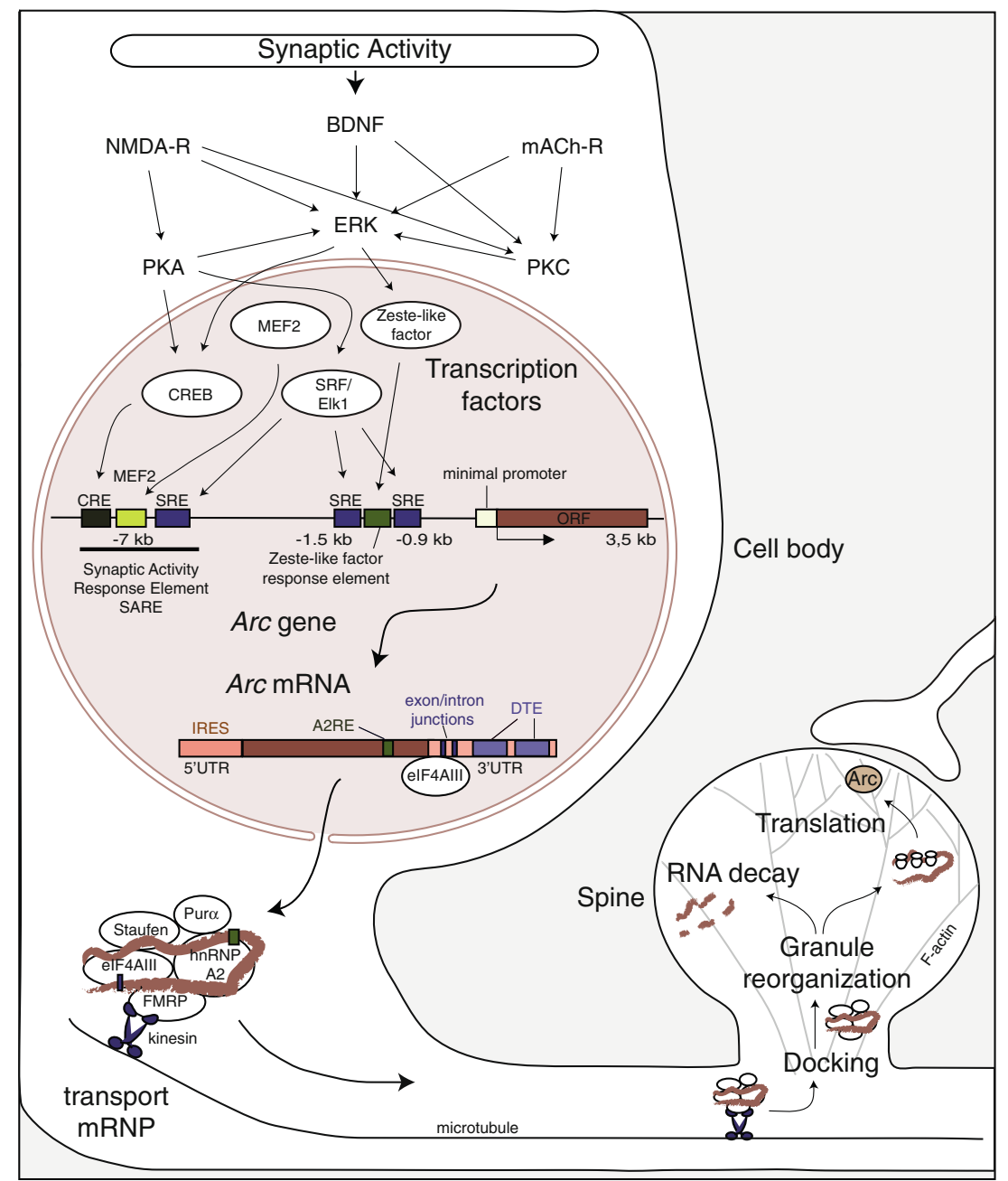

Fig. 1 Arc transcriptional regulation, transport, and docking. Arc expression is induced by signaling cascades that regulate transcription factors in response to synaptic activity. The diagram depicts the genomic organization of the synaptic activity-responsive element (SARE) and other regulatory elements upstream of the Arc open reading frame that serve as binding sites for these transcription factors. Following transcription, cis-regulatory elements of the Arc mRNA regulate its assembly into transport mRNPs. The dendritic localization and stability of the mRNA in dendrites is a result of active microtubule-based transport and local F-actin-dependent docking. Upon translation, Arc

\section{Arc RNA transport and regulation of RNA docking}

Arc mRNA is a member of the growing family of dendritically targeted mRNAs. Within $1 \mathrm{~h}$ of transcription, Arc mRNA is detected in the distal dendrites of dentate granule cells up to $300 \mu \mathrm{m}$ away from the cell bodies (Link et al. 1995; Lyford et al. 1995; Steward et al. 1998; Wallace et al. 1998). Arc mRNA is also detected in preparations of brain synaptoneurosomes and in dendrites of neurons in culture (Bagni et al. 2000; Yin et al. 2002; Havik et al. 2003; Kanai et al. 2004; Giorgi et al. 2007) indicating that Arc mRNA is present at low levels in dendrites under non-stimulating conditions. Evidence also suggests that translation of pre-
RNA is subject to rapid nonsense-mediated RNA decay. A2RE hnRNP A2 response element; $B D N F$ brain-derived neurotrophic factor; $C R E B$ CRE-binding protein; $C R E$ cAMP response element; DTE dendritic targeting elements; UTR untranslated region; ERK extracellular signalregulated kinase; IRES internal ribosome entry site; $m A C h-R$ muscarinic acetylcholine receptor; $M E F 2$ myocyte enhancing factor; $N M D A-R$ NMDA-receptor; $O R F$ open reading frame; $P K A$ cAMP-dependent protein kinase; $P K C$ protein kinase $\mathrm{C}$; $S R E$ serum response element; $S R F$ serum response factor

existing Arc mRNA stores in dendrites underlies DHPGinduced LTD (Waung et al. 2008).

RNAs destined for dendrites are born naked and packaged into messenger ribonucleoprotein (mRNP) particles (also know as transport RNPs) that contain cognate RNAbinding proteins, components of the translational machinery, and molecular motors involved in RNA transport, localization and decay. mRNP assembly is a complex and incompletely understood process that starts in the nucleus and continues in the cytoplasm (Fig. 1). The Arc 3'UTR contains two cis-acting dendritic targeting elements (DTE) required for dendritic localization of a nuclear transcribed reporter mRNA in hippocampal neurons (Kobayashi et al. 
2005). Surprisingly, removal of the $3^{\prime}$ UTR does not impair dendritic targeting of Arc RNA that is microinjected directly into the cytoplasm (Gao et al. 2008). Once in the cytoplasm, transport to dendrites appears to require a small 11 nucleotide response element within the Arc coding region that serves as a binding site for heterogeneous nuclear ribonucleoprotein (hnRNP) A2. The A2RE is found in several other dendritically targeted mRNAs, and there is indication that $\mathrm{A} 2$ can sequester the mRNAs encoding Arc and $\alpha$-CaMKII and package them together into the same particle, suggesting a partial co-regulation of the two mRNAs (Gao et al. 2008). The authors raise the possibility that $c i s$-acting elements in the Arc 3'UTR mediate steadystate levels of mRNA expression in dendrites, while the A2RE mediates activity-dependent transport. Other components of Arc mRNPs are the translational repressor proteins fragile-X mental retardation protein (FMRP) and Pur $\alpha$ that inhibit translation of the mRNA during transport (Zalfa et al. 2003; Kanai et al. 2004). Besides its role as a translational repressor, FMRP can act as an adaptor protein for the molecular motor complex kinesin (Davidovic et al. 2007; Dictenberg et al. 2008). This interaction increases during neuronal activity and can regulate transport of $\alpha$-CaMKII mRNA, suggesting a mechanism whereby neuronal activity may enhance transport of mRNPs in general.

Kinesin as a motor complex for Arc mRNA is also indicated by the fact that $A r c$ is co-purified with the kinesin heavy chain KIF5 (Kanai et al. 2004). Moreover, constructs encoding the 3'UTR of Arc in cultured neurons undergo fast, directed movement with a maximum speed of $60 \mu \mathrm{m} /$ min, indicating active motor-dependent transport (Dynes and Steward 2007). This transport in unstimulated neurons is similar to that observed for other mRNPs or vesicles: particles can be stationary, oscillate, move bidirectionally, or move in a single direction over short periods, averaging a speed of $14-17 \mu \mathrm{m} / \mathrm{min}$ (Dynes and Steward 2007). The translocation rate of $\operatorname{Arc}$ mRNA in vivo $(300 \mu \mathrm{m}$ in $1 \mathrm{~h})$ is consistent with a fast, directed transport interspersed with pauses of variable duration. However, this calculation does not account for the possibility that transport of mRNPs may be altered by neuronal activity. Transport of $\alpha$-CamKII mRNA becomes biased toward the anterograde direction when cells are depolarized (Rook et al. 2000). Since this RNA is partially co-packaged with $A r c$, this phenomenon may also apply to $A r c$ transport.

Within dendrites, Arc accumulates in regions where synapses have been recently activated (Steward et al. 1998; Steward and Worley 2001). This depends on local actin polymerization and signaling through NMDARs and Rho kinase (Huang et al. 2007). The data suggest that Arc localization results from microtubule-dependent fast transport followed by F-actin-dependent docking, as it does for many localized RNAs in other cell types (Lopez de and Jansen
2004). An interesting feature here is that Arc protein itself is required for stabilization of F-actin at active synapses, suggesting a positive feedback loop (Messaoudi et al. 2007; Bramham 2008). Since F-actin is necessary but not sufficient for Arc localization, additional local signals are required for this docking. ERK activation was identified as one of these signals, but the sequence of events in this process is not entirely elucidated (Huang et al. 2007).

\section{Translational control and local arc synthesis}

A variety of post-transcriptional mechanisms exist for controlling the timing, location, and amount of protein synthesis in response to synaptic inputs, neuronal firing activity, or hormonal influences. One important feature of Arc regulation is translation-dependent RNA decay (Fig. 1). Work of Giorgi and colleagues suggests that Arc is a physiological target for a process known as nonsense-mediated RNA decay (NMD) (Giorgi et al. 2007; Peebles and Finkbeiner 2007). Conventionally, NMD serves as a quality control surveillance mechanism for the rapid elimination of aberrant mRNAs with stop codons situated upstream of a splice site (Wittmann et al. 2006; Giorgi et al. 2007; Ni et al. 2007; Chang et al. 2007). During pre-mRNA splicing in the nucleus, exon-junction complex (EJC) proteins consisting of an RNA-binding tetrameric core (eI4AIII, MLN51, Y14, and MAGOH) are deposited on the RNA and subsequently removed by the ribosome during the first round of translation, allowing bulk rounds of translation to proceed. In the advent of a premature stop codon, recruitment of a key NMD factor, UPF1, leads to degradation of the RNA after a single round of translation (Maquat 2004). Arc becomes a natural target for NMD by virtue of the presence of two introns in the 3'UTR of the gene, resulting in EJC assemblage downstream of the stop codon (Giorgi et al. 2007). In hippocampal neurons stimulated with BDNF, 59\% of Arc granules in dendrites colocalize with the core NMD protein eI4AIII, strongly suggesting that Arc has not been translated prior to reaching the dendrite. Confirming the functional impact of NMD, knockdown of eI4AIII enhances Arc RNA and protein expression and selectively increases the amplitude of miniature excitatory postsynaptic currents (mEPSCs). While NMD severely limits Arc synthesis, more than one round of translation is distinctly possible. Some $41 \%$ of Arc RNA granules in dendrites do not colocalize with eIF4AIII, indicating that these transcripts survived the first round of translation. The estimated half-life of $\operatorname{Arc}$ mRNA in dissociated hippocampal neurons is 47 min (Rao et al. 2006). As discussed later on, the rapid degradation of $A r c$ by NMD is a highly distinctive feature that fits conceptually with the requirement for sustained translation of new Arc mRNA in LTP consolidation. 
Translation initiation is the rate-limiting step in protein synthesis, and therefore subject to stringent regulation and modulation (Proud 2007; Sonenberg and Hinnebusch 2009). Formation of a translationally competent ribosome relies on the cooperation of numerous translation factors. A key component in this process is the translation factor eukaryotic initiation factor 4E (eIF4E), which binds to the 7-methylguanosine 5-triphosphate cap on the $5^{\prime}$-end of the mRNA and promotes recruitment of the $43 \mathrm{~S}$ preinitiation complex. Phosphorylation of eIF4E on $\mathrm{Ser}^{209}$ correlates with enhanced rates of cap-dependent translation, whereas hypo-phosphorylation is associated with decreased translation (Richter and Sonenberg 2005). eIF4E is phosphorylated by MAP kinase integrating kinase-1 (MNK1) in response to ERK activation. The mammalian target of rapamcyin complex 1 (mTORC1) also plays an important role by regulating the availability of the eIF4E for cap-binding. eIF4E is sequestered by eIF4E-binding proteins (eIF4EBPs), but mTORC1-dependent phosphorylation of the binding protein induces release of sequestered eIF4E and facilitates initiation.

ERK and mTOR operate synergistically in regulation eIF4E in many situations requiring enhanced protein synthesis, including during LTP and mGluR-LTD in the hippocampal CA1 region (Banko et al. 2005, 2006; CostaMattioli et al. 2009). In the dentate gyrus, LTP consolidation requires a surprisingly sustained period of Arc synthesis starting within $10 \mathrm{~min}$ of HFS and lasting for 2-4 h (Messaoudi et al. 2007). A recent study examined the regulation of translation factor activity during the critical period of Arc-dependent consolidation (Panja et al. 2008). The authors found that HFS elicits rapid and sustained phosphorylation of the eIF4E which parallels the time-window of Arc synthesis. ERK-dependent signaling to MNK1 was necessary for eIF4E phosphorylation, enhanced initiation complex formation, and Arc protein expression. Synthesis of Arc mRNA persists for at least 30 min post-HFS and is also ERK dependent. Blockade of ERK signaling eliminates Arc mRNA, consistent with the sustained translation and rapid degradation of new Arc mRNA during LTP maintenance. Importantly, pharmacological inhibition of MNK1 abolishes Arc protein expression but not Arc mRNA. Taken together, this suggests a coordination role for ERK in the transcription, docking, and translation of Arc mRNA. Surprisingly, Panja et al. (2008) also find that LTP maintenance and Arc expression are not affected by inhibition of mTORC1 signaling with rapamycin. Consistent with this finding, mTOR activation was dispensable for enhanced initiation complex formation. Although mTOR signaling to p70S6 kinase and ribosomal protein S6 was activated during LTP, inhibition of this signaling by rapamycin did not impact LTP maintenance during $4 \mathrm{~h}$ of recording.
The exact function of eIF4E phosphorylation remains enigmatic. Increases in eIF4E activity increase translation of subsets of mRNAs rather than affecting global translation (Richter and Sonenberg 2005). It has been speculated that decreased binding of eIF4E to the cap structure as a result of phosphorylation could serve to speed scanning of the preinitiation complex to the translation startsite or accelerate recruitment of new initiation complexes (Proud 2007). Such a mechanism could be decisive for transcripts like Arc that are only weakly initiated due to the strong secondary structure of their 5'UTRs. The 5'UTR of Arc and that of several other dendritically localized $\mathrm{mRNAs}$ contains an internal ribosomal entry site (IRES) which is capable of mediating cap-independent translation in vitro. Such a mechanism could be important when cap-dependent mechanisms are saturated, as may occur during intensive bouts of protein synthesis.

Neuronal activity also modulates the elongation step of protein synthesis through regulation of eukaryotic elongation factor-2 (eEF2) (Scheetz et al. 2000; Sutton et al. 2007). eEF2 is a GTP-binding protein that mediates translocation of peptidyl-tRNAs from the A-site to the P-site on the ribosome. Phosphorylation of eEF2 on $\mathrm{Thr}^{56}$ inhibits eEF2-ribosome binding and arrests peptide chain elongation (Ryazanov et al. 1988; Nairn and Palfrey, 1987). Paradoxically, eEF2 is phosphorylated in protein synthesisdependent forms of LTP and LTD; yet, synthesis of several plasticity-related proteins, including Arc, is maintained (Chotiner et al. 2003; Kanhema et al. 2006; Park et al. 2008; Panja et al. 2008). By making elongation the ratelimiting step for protein synthesis, it has been suggested that eEF2 phosphorylation may selectively favor the translation of weak initiators such as Arc (Walden and Thach 1986; Scheetz et al. 2000; Belelovsky et al. 2005; Kanhema et al. 2006). Recent work shows that rapid Arc synthesis underlying mGluR-dependent LTD is dependent on eEF2 phosphorylation (Park et al. 2008).

In hippocampal neuronal cultures, NMDAR activation of the PKA pathway enhances Arc protein expression during pharmacological blockade of Arc transcription (Bloomer et al. 2008), but the downstream mechanisms are currently unknown.

\section{Arc protein function in long-term synaptic plasticity}

In vivo studies in dentate gyrus have shown that inhibition of Arc by intrahippocampal infusion of Arc antisense (AS) oligodeoxynucleotides impairs the maintenance but not the induction of LTP (Guzowski et al. 2000; Messaoudi et al. 2007). In Arc knockout mice, early phase LTP is enhanced while late phase LTP is blocked in both the dentate gyrus in vivo and in the CA1 region of acute hippocampal slices (Plath et al. 2006). Recently, the dynamics of Arc function 
were explored by local infusion of Arc AS at various times after LTP induction (Messaoudi et al. 2007). Infusion of Arc AS at $2 \mathrm{~h}$ (but not $4 \mathrm{~h}$ ) post-HFS led to complete and permanent reversal of LTP and rapid knockdown of induced Arc mRNA and protein expression. Brief infusion of Arc AS at 15 min post-HFS reverses LTP only transiently, and the recovery phase is accompanied by enhanced Arc synthesis. The evidence suggests: (1) that LTP consolidation requires sustained Arc translation during a time-window that starts within minutes of LTP induction and lasts for 2-4 h, and (2) that Arc protein underlying LTP consolidation is rapidly degraded (Fig. 2).

In addition to gene expression, formation of late phase LTP involves enduring structural changes, including expansion of the postsynaptic density and enlargement of postsynaptic dendritic spines (Matsuzaki et al. 2004; Bourne and Harris 2008). These structural changes depend on accumulation of F-actin as well as new protein synthesis (Fukazawa
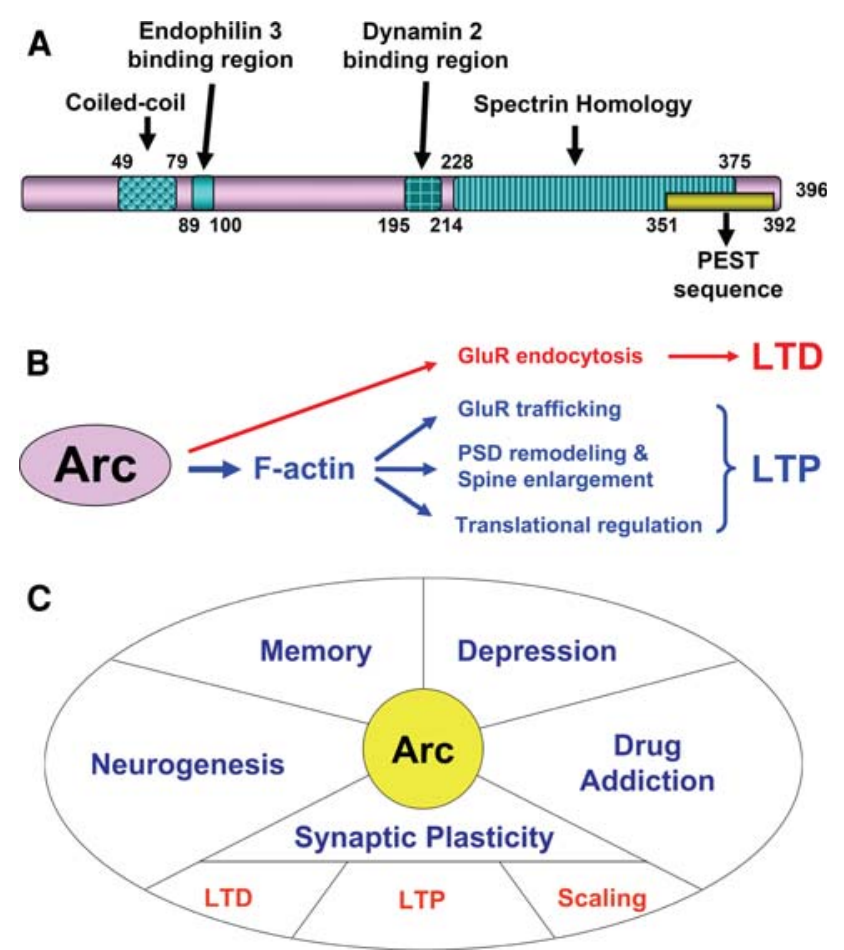

Fig. 2 Arc protein function. a Schematic representation of Arc protein domains and binding motifs. The endophilin and dynamin binding sites mediate AMPAR endocytosis in synaptic depression. The PEST sequence, a region rich in the amino acids proline $(\mathrm{P})$, glutamate $(\mathrm{E})$, serine (S), or threonine (T), could target Arc for proteasomal degradation. $\mathbf{b}$ Arc is required for LTP consolidation through regulation of Factin expansion. F-actin functions in PSD remodeling and spine enlargement, and is recently implicated in the sustained phosphorylation of translation initiation factor eIF4E during LTP. Synaptic depression in homeostatic plasticity and LTD is mediated by AMPAR endocytosis. c Arc functions. Arc plays critical roles in synaptic plasticity and memory storage. Functions in neurogenesis, drug addiction, and resilience to stress have been suggested but causal roles have not been defined et al. 2003; Bramham 2008; Tanaka et al. 2008). One of the major regulators of F-actin dynamics in spines is cofilin, which in its phosphorylated state promotes actin polymerization. In the study of Messaoudi et al. (2007), inhibition of LTP consolidation was associated with rapid dephosphorylation of hyperphosphorylated cofilin and corresponding loss of nascent F-actin at medial perforant path synapses. Importantly, the ability of Arc AS to reverse LTP was blocked by the F-actin stabilizing drug, jasplakinolide. Taken together, this strongly suggests that Arc promotes LTP consolidation through regulation of actin dynamics.

F-actin formation has long been implicated in the finelocalization of the translational machinery and the activity of certain F-actin associated translation factors (Smart et al. 2003; Gross and Kinzy 2007). This prompted investigation of whether regulation of actin dynamics by newly synthesized Arc contributes to the maintenance of eIF4E phosphorylation during LTP in the dentate gyrus in vivo (Tiron and Bramham 2008). Remarkably, infusion of Arc AS during LTP maintenance blocked hyperphosphorylation of eIF4E. The same treatment had no effect on enhanced rpS6 phosphorylation, suggesting translation factor specificity. Furthermore, prior infusion of jasplakinolide rescued LTP and eIF4E phosphorylation. Thus, Arc synthesis is coupled to F-actin dynamics and regulation of eIF4E phosphorylation during LTP.

Several lines of evidence support a role for brain-derived neurotrophic factor (BDNF) as a trigger of protein synthesis-dependent LTP (Bramham and Messaoudi 2005; Lynch et al. 2007). HFS of excitatory input triggers release of BDNF leading to activation of postsynaptic TrkB receptors which can mobilize further BDNF secretion. Stimulus protocols generating late phase LTP are associated with a period of sustained BDNF release, and disruption of the BDNF-TrkB interaction blocks late phase LTP. Exogenous application of BDNF induces a lasting potentiation of excitatory synaptic transmission (BDNF-LTP) in several brain structures. BDNF-LTP in the dentate gyrus is transcription dependent, occluded by prior expression of late phase LTP, and associated with transport of Arc mRNA into granule cell dendrites (Messaoudi et al. 2002; Ying et al. 2002). Recently, inhibition of Arc synthesis with AS treatment was shown to abolish BDNF-LTP induction without affecting baseline transmission (Messaoudi et al. 2007). Furthermore, the maintenance of BDNF-LTP and cofilin phosphorylation are rapidly inhibited by Arc AS application during a critical time window, as seen for HFS-LTP. Thus, exogenous BDNF activates Arc transcription and Arc synthesis-dependent LTP.

There is also strong evidence for Arc involvement in activity-dependent depression of excitatory synaptic transmission observed in mGluR-dependent LTD and homeostatic plasticity (Fig. 2). These effects are mediated through 
interaction of Arc with components of the endocytic machinery (dynamin and endophilin 2/3) leading to internalization of surface AMPAR-type glutamate receptors (Chowdhury et al. 2006; Rial Verde et al. 2006; Shepherd et al. 2006; Park et al. 2008; Waung et al. 2008). Neurons expressing the Arc transgene have reduced evoked and spontaneous AMPAR-mediated EPSCs with no changes in NMDAR-mediated currents (Rial Verde et al. 2006), indicating a mechanism specific to postsynaptic AMPARs. During homeostatic plasticity, steady-state increases in neuronal activity lead to a downscaling of surface AMPAR expression and global weakening of excitatory synaptic inputs without altering the relative strengths of the inputs (Turrigiano 2008). In hippocampal neuronal cultures, decreases in neuronal firing activity during tetrodotoxin treatment enhance Arc expression while increases in activity in the presence of a GABA-A receptor blocker decrease Arc expression (Chowdhury et al. 2006). The homeostatic scaling of AMPARs is abolished in Arc KO neurons, while Arc overexpression prevents the increase in AMPAR function associated with chronic activity blockade (Chowdhury et al. 2006; Rial Verde et al. 2006; Shepherd et al. 2006; Waung et al. 2008).

mGluR-LTD induced by low-frequency stimulation or application of DHPG requires rapid protein synthesis and endocytosis of AMPARs. Waung et al. (2008) showed the DHPG-LTD in CA1 pyramidal cells requires rapid translation of $A r c$ in dendrites. Furthermore, acute inhibition of Arc synthesis blocked a persistent increase in AMPAR endocytosis rates. Similarly, in hippocampal slices from Arc KO mice, pharmacologically and synaptically evoked mGluR-dependent LTD are both suppressed and treatment with DHPG fails to decrease surface expression of GluR1 (Park et al. 2008). Park et al. (2008) also provide compelling evidence that enhanced translation of Arc during mGluR-LTD relies on eEF2 function. Arc synthesis and mGluR-LTD are inhibited in acute hippocampal slices from eEF2 kinase KO mice, but the wildtype phenotype can be reinstated in slices exposed to low-dose cycloheximide, a treatment known to enhance eEF2 phosphorylation. As mentioned previously, the RNA-binding protein FMRP is proposed to physiologically repress translation of target mRNAs in dendrites, including Arc (Zalfa et al. 2003). mGluR activation results in dephosphorylation of FMRP and relieves the translational inhibition (Antar et al. 2004; Narayanan et al. 2007). In fmrl KO mice, aberrantly enhanced translation is associated with elongated spines and behavioral deficits mirroring the mental retardation syndrome. Park et al. (2008) show that rapid synthesis of Arc is impaired in fmrl KO mice. FMRP, however, is not required for eEF2 phosphorylation, suggesting parallel pathways from group I mGluRs to eEF2 kinase and FMRP in the regulation of Arc synthesis in mGluR-LTD.
Studies exploring the role of Arc in NMDAR-dependent LTD have produced mixed results. Favoring a role, LFSinduced LTD of the Schaffer collateral-CA1 synapse is reduced in acute hippocampal slices from Arc KO mice (Plath et al. 2006) and overexpression of Arc transgene occludes NMDAR-dependent LTD in organotypic hippocampal slices (Rial Verde et al. 2006). On the other hand, stimuli that typically induce LTD (1 Hz LFS) do not induce Arc transcription or translation (Steward and Worley 2001). In the study of Waung et al. (2008), LTD induced by application of NMDA only transiently increased AMPAR endocytosis rates and did not induce Arc expression, or require Arc protein. However, in agreement with previous work (Rial Verde et al. 2006), overexpression of GFP-tagged Arc inhibited NMDA-induced endocytosis of AMPARs. It has therefore been suggested that extreme changes in Arc levels (knockout or overexpression) impact both NMDAR and mGluR-LTD, whereas mGluR-LTD is selectively sensitive to more subtle activity-evoked changes in Arc synthesis (Waung et al. 2008).

\section{Arc protein localization, post-translational modification, and turnover}

The known domain structure of the 396 amino acid Arc protein is shown in Fig. 2a. Biochemically, Arc co-sediments with crude F-actin but not with more highly purified actin suggesting an indirect association of Arc with the cytoskeleton via an actin-binding protein (Lyford et al. 1995). Cofilin activity is regulated by Arc synthesis, but there is no evidence of a direct interaction between cofilin and Arc. Pulldown and co-immunoprecipitation experiments suggest that Arc complexes with PSD-95 and CaMKII in the PSD fraction (Husi et al. 2000; Donai et al. 2003). A recent extensive analysis employing yeast 2hybrid, co-immunoprecipitation, and binding assays identified Arc binding domains for endophilin 3 and dynamin 2. Arc also has a coiled-coil domain and a spectrin homology domain in the C-terminal half which may mediate interactions with other spectrin repeat containing proteins (Link et al. 1995; Lyford et al. 1995), though no such interactions have been described.

Morphologically, immunocytochemical detection of endogenous Arc at the light microscopic levels shows colocalization of Arc with the cytoskeleton, synaptic puncta, and the nucleus (Link et al. 1995; Lyford et al. 1995; Steward et al. 1998; Bloomer et al. 2007; Chowdhury et al. 2006). At the ultrastructural level, immuno-electronmicroscopy shows Arc throughout dendritic spines, with concentrated labeling in the PSD and detectable labeling in vesicular-like structures (Moga et al. 2004; Rodriguez et al. 2005; Chowdhury et al. 2006). Following LTP induction, 
Arc protein is found across the dendritic arbor of principal neurons of the hippocampus, and electron microscopy reveals selective accumulation of Arc protein in spines within the termination zone of the activated fibers (Rodriguez et al. 2005). The exact sites of dendritic Arc synthesis are unknown, but evidence for polyribosome and RNA trafficking to spines (Ostroff et al. 2002; Havik et al. 2003; Yoshimura et al. 2006), docking of Arc mRNA to the cytoskeleton (Huang et al. 2007), and Arc synthesis in isolated synaptoneurosomes (Yin et al. 2002) suggests that synthesis occurs at least partly in spines.

Arc accumulates in the nucleus, but its function there is unknown. As Arc lacks a consensus nuclear localization signal (NLS), its nuclear transport may require domain-specific protein interactions or post-translational modifications. A protein known as Amida has been implicated in Arc nuclear import (Irie et al. 2000). Evidence from COS7 cells suggests that Arc is ferried to the nucleus upon binding to the region between two canonical NLSs in Amida, but information from neurons is lacking. Inside the nucleus, Arc forms multiple nuclear puncta and associates with promyelocytic leukemia nuclear bodies (PML-NBs) (Bloomer et al. 2007). PML-NBs are discrete nuclear foci present in most mammalian nuclei and have been implicated as sites of protein storage and release, post-translational modification, transcriptional activation and repression, and heterochromatin formation (Zhong et al. 2000; Borden 2008). According to Bloomer et al. (2007), Arc interacts with PML-NBs by binding to a nuclear spectrin isoform ( $\left.\beta \operatorname{SpIV} \sum 5\right)$. Arc binding is mediated by a portion of the $\mathrm{N}$ terminus (aa 26-154) containing the coiled-coil domain and does not involve the $\mathrm{C}$-terminal spectrin repeat domain.

In LTP experiments, Arc AS induces a 50\% knockdown of Arc protein expression within $1 \mathrm{~h}$ of infusion, consistent with rapid turnover of Arc protein underlying LTP consolidation (Messaoudi et al. 2007). In cultured hippocampal neurons, Arc degradation is blocked by pharmacological inhibition of the ubiquitin proteasomal system (UPS). Arc also has a PEST sequence [rich in proline $(\mathrm{P})$, glutamate (E), serine (S), and threonine $(\mathrm{T})]$ in its C-terminus (residues 351-392) which may target it for proteasomal degradation (Rao et al. 2006). In the presence of proteasomal inhibitors, BDNF-induced increases in Arc protein levels reach baseline levels in $3 \mathrm{~h}$ but are stably elevated in controls. These results are at odds with a study employing the photoconvertible fluorescent protein monomeric Eos, in which photoconverted Arc-Eos exhibited stable levels of fluorescence for at least $3 \mathrm{~h}$ (Bloomer et al. 2008). Further time-lapse imaging studies examining the rates of Arc degradation in neuronal subcompartments are needed.

The post-translational addition of a protein called small ubiquitin-like modifier (SUMO) has emerged as major mechanism for regulating the intracellular localization, pro- tein interactions, turnover, and activity of target proteins (Meulmeester and Melchior 2008). Post-translational modification by SUMO, a family of proteins of approximately $10 \mathrm{kD}$, is carried out by a cascade of enzymes similar to that involved in ubiquitination. Recent work has identified two consensus SUMOylation sites in Arc that direct its subcellular localization to dendrites and the cytoskeleton (Nair et al. 2009, unpublished observations). In vitro SUMOylation assays performed with immunoprecipitated Arc demonstrate direct Arc SUMOylation, and single amino acid substitutions (lysine to alanine) of the consensus SUMOylation sites disrupt the subcellular localization pattern of Arc in dendrites. Interestingly, BDNF treatment of hippocampal neurons induces colocalization of endogenous Arc with SUMO1 and PSD-95. Following LTP induction in dentate gyrus of anesthetized rats, SUMOylated Arc massively accumulates in the cytoskeletal fraction relative to cytosolic, membrane, or nuclear fractions. These data raise the intriguing possibility that SUMOylation of Arc directs its interaction with the cytoskeleton during LTP consolidation.

\section{Arc and memory consolidation}

Guzowski and colleagues originally showed that intrahippocampal infusion of Arc AS impairs LTP consolidation and long-term spatial memory without affecting acquisition and short-term memory performance (Guzowski et al. 2000). In a recent in-depth behavioral analysis of homozygous Arc knockout mice, Plath et al. (2006) establish a selective requirement for Arc in long-term memory for a variety of hippocampal-dependent and hippocampal-independent tasks, including spatial learning in the Morris water maze, auditory and context-dependent fear conditioning, conditioned taste aversion, and object recognition. Using Arc AS infusion, McIntyre et al. (2005) show that Arc synthesis in the dorsal hippocampus is also necessary for inhibitory avoidance memory. Moreover, hippocampal Arc synthesis and memory performance were both modulated by activation of $\beta$-adrenoreceptors in the basolateral complex of the amygdala, indicating an important role for extrinsic inputs in modulating Arc function in the hippocampus. In the lateral amygdala, Pavlonian fear conditioning results in enhanced expression of Arc that is ERK dependent and selectively required in the formation of long-term memory (Ploski et al. 2008). Together, these studies support a role for Arc in diverse forms of long-term memory in the rodent brain.

Studies over the last decade have exploited the rapid expression of immediate early genes such as Arc, c-fos, zif268, and homerla to map neuronal populations and circuits engaged in distinct forms of learning (Guzowski et al. 1999; Montag et al. 1999; Vazdarjanova et al. 2002; Kelly 
and Deadwyler 2003; Montag-Sallaz and Montag 2003; Vazdarjanova and Guzowski 2004; Gusev et al. 2005; Kubik et al. 2007; Soule et al. 2008). Work of Vazdarjanova and Guzowski (2004) further established a tight link between Arc transcription and neural activity specifically associated with information processing in hippocampal subfields. Taking advantage of Arc mRNA processing (splicing) in the nucleus and rapid transit to cytoplasm, these authors used fluorescence in situ hybridization of nuclear and cytoplasmic Arc to map the effects of multiple behavioral experience in the same rat. They were able to show that repeated behavioral exploration of an environment elicited Arc transcription in the same discrete population of hippocampal pyramidal cells, while exposure to two completely different environments activates a partly nonoverlapping neuronal population. These observations are quantitatively and qualitatively similar to those obtained in single-unit recording studies of place cell firing in the hippocampus (Guzowski et al. 1999). In a recent study, Miyashita and colleagues studied the role of the medial septal input to the hippocampus on Arc mRNA expression in rats walking on a closed track. The medial septum was inactivated by intraseptal infusion of tetracaine anesthetic, a treatment previously shown to attenuate the hippocampal theta rhythm without affecting the location-specific firing of CA3 and CA1 neurons (Fletcher et al. 2007; Miyashita et al. 2009). Behaviorally induced Arc expression was blocked by this treatment, suggesting that $\operatorname{Arc}$ transcription in CA3-CA1 ensembles depends on input from medial septum and possibly the presence of the hippocampal theta rhythm.

Memory loss in Alzheimer's disease (AD) is associated with loss of connectivity in hippocampal and cortical networks. In transgenic mice expressing human amyloid precursor protein (hAPP) and hAPP-derived amyloid- $\beta(\mathrm{A} \beta)$, Arc expression is reduced primarily in granule cells of the dentate gyrus (Palop et al. 2005). In cultured cortical neurons, BDNF-induced Arc expression is suppressed even at sublethal levels of A $\beta$ (Wang et al. 2006). Other investigators reported that exposure of dissociated hippocampal neurons to neurologically active $\mathrm{A} \beta$ oligomers termed $\mathrm{A} \beta$-derived diffusible ligands (ADDLs) produces upregulation of Arc and lengthening of dendritic spines followed by reductions in synapse density (Wang et al. 2002; Lacor et al. 2004; Viola et al. 2008). Together, this work suggests that dysregulation of Arc expression could contribute to cognitive impairment and memory loss in AD.

Aging is associated with deterioration of neuronal function in the hippocampus rather than frank cell loss and degeneration. Studies in rats, monkeys, and humans point to the dentate gyrus as the region most susceptible to the functional decline with advanced age. Using fluorescence in situ hybridization, Small et al. (2004) showed that the proportion of granule cells expressing Arc RNA following spatial exploration decreases with advanced age, whereas pyramidal neurons of $\mathrm{CA} 3$ and $\mathrm{CA} 1$ region show no agerelated change in Arc expression. As proposed by Burke and Barnes (2008), the decline in behaviorally evoked Arc expression in dentate granule cells could reflect age-related impairments in place cell activity and place field formation or uncoupling of $A r c$ transcription from granule cell activity.

\section{Arc, antidepressants, and drugs of abuse}

The behavioral effects of antidepressants in animal models of depression and the therapeutic effects in humans typically take several weeks to develop. Upregulation of BDNF expression and enhanced TrkB receptor signaling in the dentate gyrus, hippocampus, and cortex is implicated in the mechanism of action of antidepressant drugs such as the selective serotonin reuptake inhibitors (SSRIs). While BDNF has diverse functions, it is commonly thought that TrkB signaling during antidepressant treatment promotes or restores plasticity in affected circuits through regulation of gene expression (Castren et al. 2006; Dagestad et al. 2006). As discussed, Arc has been identified as a critical effector gene for BDNF in the context of BDNF-induced LTP in the dentate gyrus. Several studies have reported upregulation of Arc in forebrain structures in which TrkB signaling is enhanced by antidepressants (Pei et al. 2003; Alme et al. 2007; Larsen et al. 2007; Molteni et al. 2008). A recent microarray study further identified a panel of nine genes that are strongly upregulated with Arc during BDNF-LTP and HFS-LTP in the dentate gyrus and five genes selected for validation by RT-PCR and in situ hybridization were confirmed upregulated in dentate granule cells (Wibrand et al. 2006). The gene set includes several genes with known synaptic roles, such as neuronal activity-regulated pentraxin (Narp) and neuritin. Interestingly, the BDNF-regulated genes exhibited a region-specific pattern of upregulation in the prefrontal cortex, hippocampus, and dentate gyrus, after chronic (but not acute) treatment with the SSRI fluoxetine (Alme et al. 2007).

Downregulation of BDNF following traumatic life events or stress is thought to contribute to depression, but animal studies clearly indicate that removal of BDNF in rat forebrain does not precipitate depressivelike behavior (Krishnan and Nestler 2008). Nevertheless, in a study employing predator scent as stressor, rats whose behavior is minimally disrupted by exposure to the predator scent had increased levels of Arc mRNA expression in hippocampus, whereas the rats whose behavior was severely disrupted demonstrated no such upregulation (Kozlovsky et al. 2008). These data were 
interpreted in support of a possible role for Arc expression in resilience to adverse life events. At the moment, however, there is no evidence causally linking Arc to any aspect of depression or the action of antidepressants, nor is there solid evidence that depression or recovery from depression involves alterations in the capacity for long-term modification of existing synapses (LTP and LTD) as opposed to synaptogenesis or neurogenesis.

Drug addiction involves adaptive changes in the nervous system that are maintained after drug withdrawal (Hyman et al. 2006). It has been suggested that mechanisms subserving memory storage are hijacked in the context of drug addiction and relapse. Opiate withdrawal, for example, leads to the emergence of an aversive state that can be conditioned to a specific environment. Reactivation of these withdrawal memories has been suggested to trigger relapse of drug-seeking behavior in abstinent opiate addicts. A pair of recent studies demonstrated enhanced Arc expression, most prominently in the basolateral nucleus of the amygdala, during the acquisition of conditioned place aversion and following re-exposure of rats to the withdrawal-paired environment (Lucas et al. 2008; Li et al. 2009). In the study of Li et al. (2009), Arc expression was seen following place aversion elicited by conditioned naloxone-precipitated drug withdrawal following exposure to a single dose of morphine. Another important issue is whether long-term changes can develop after the first voluntary drug exposure. Fumagalli et al. (2009) found that a single session of intravenous cocaine self-administration increased the levels of Arc (but not zif268) in medial prefrontal cortex relative to yoked controls receiving cocaine or vehicle infusion (Fumagalli et al. 2009). The role of Arc in alcoholism has also been studied in rat models. The anxiolytic effects of acute ethanol exposure are associated with enhanced BDNF and TrkB expression, ERK phosphorylation, Arc expression and increased dendritic spine density in the central and medial amygdala (but not in the basolateral amygdala) (Pandey et al. 2008). Conversely, these effects were all decreased during ethanol withdrawal associated with increased anxiety-like behavior. Infusion of BDNF into the central amygdala normalized Arc expression and protected against withdrawal-related anxiety in ethanoltreated rats. Intra-amygdala infusion of Arc AS was also reported to increase anxiety-like behavior in rats that were not given ethanol.

The psychostimulant drugs methylphenidate and D-amphetamine are widely prescribed in the treatment of attention-deficit/hyperactivity disorder (ADHD). Two recent studies in rats report age-specific and brain regionspecific effects of these drugs on expression of BDNF and Arc. In adult rats administration of psychostimulants increased $\operatorname{Arc}$ mRNA levels in many forebrain structures, while in juveniles $\operatorname{Arc}$ mRNA expression was decreased in the hippocampus and parietal cortex (Chase et al. 2007; Banerjee et al. 2009). The authors suggest that decreased $A r c$ expression in juveniles may be related to the reported long-term harmful effects of psychostimulants in animal models, with possible ramifications for the treatment of children diagnosed with ADHD.

\section{Arc and neurogenesis}

Neurogenesis is a vital form of neural plasticity occurring solely in the subventricular zone (SVZ) of the olfactory bulb and the subgranular zone (SGZ) of the hippocampal dentate gyrus. Ongoing throughout life in the adult mammalian brain, neurogenesis encompasses the proliferation of neural stem and progenitor cells as well as their differentiation, migration and eventual incorporation into the preexisting circuitry (Doetsch and Hen 2005; Zhao et al. 2008) Alongside activity-dependent synaptic plasticity (Morris 2006; Pastalkova et al. 2006), neurogenesis of dentate granule cells (DGCs) is recognized as a major contributor to hippocampal-dependent memory function (Shors et al. 2001; Bruel-Jungerman et al. 2005; Leuner et al. 2006; Zhang et al. 2008; Farioli-Vecchioli et al. 2008; Imayoshi et al. 2008). Despite a constant supply of neuronal precursors provided by the progenitor cells, only a small fraction of these survive to develop, mature and functionally integrate into the pre-existing neuronal networks (Cameron et al. 1993; Cameron and McKay 2001; Dayer et al. 2003; Zhao et al. 2008). A major challenge is thus to understand the stringent selection process that governs the selective survival and integration of adult-born dentate granule cells.

Given the crucial role for Arc in LTP consolidation, Kuipers et al. (2009) considered that the ability to induce Arc in newborn granule cells could be used to map their functional maturation. LTP was induced in the perforant path and Arc expression was examined in cells birthmarked by bromodeoxyuridine (BrdU) injection during the first 4 weeks of maturation. Contrary to the expectation, LTP induction within the perforant path does not detectably increase Arc expression in newborn DGCs, suggesting that young neurons are refractory to synaptically evoked Arc expression. Furthermore, Arc is expressed from a very early post-mitotic age - as early as 1 day after birth, with its expression strongly associated with the long-term survival and neuronal differentiation of newly generated cells. Since such early expression (i.e. 1 or 7 days post-mitosis) precedes the formation of glutamatergic synapses on new neurons (Overstreet-Wadiche and Westbrook 2006; Zhao et al. 2006; Toni et al. 2007), these findings suggest a novel function for Arc in neurogenesis, distinct from its role in LTP, LTD and homeostatic synaptic plasticity. 
Such early and spontaneous expression of Arc has not been observed for other IEGs, including c-fos, zif268, or homer1a (Jessberger and Kempermann 2003; Bruel-Jungerman et al. 2006; Kee et al. 2007). The latter IEGs can be induced experimentally on a developmental time course that corresponds to the time of synapse formation at approximately 2 weeks (Schmidt-Hieber et al. 2004; $\mathrm{Ge}$ et al. 2007). The spontaneous expression in early newborn cells (less than 4 weeks of age), appears to be a unique property of Arc among the IEGs. The refractory nature of new neurons to HFS-evoked Arc induction is also intriguing and all the more surprising since 1-3-week-old neurons have lower thresholds for LTP induction relative to preexisting DGCs (Bruel-Jungerman et al. 2006; Kee et al. 2007; Jessberger and Kempermann 2003). The latter does not exclude the possibility that newborn neurons, with their own specific synaptic properties, display a form of LTP that is independent of Arc expression. Enhanced behavioral induction of Arc has been reported, however, in 5-monthold DGCs relative to the older, pre-existing neurons (Ramirez-Amaya et al. 2006) as well as in 10-week-old DGCs (Kee et al. 2007), suggesting that neurons undergo an early refractory period to evoked Arc expression which gives way to a state of heightened sensitivity as the neurons mature. Systematic comparisons of behaviorally-evoked and HFS-evoked expression of Arc and other IEGs across the full time-frame of DGC maturation are needed to test this hypothesis.

In the study of Kuipers and colleagues, a progressive increase in double BrdU/Arc positive cells was paralleled by a gradual time-dependent decline of Arc-negative new DGCs, raising the possibility that early Arc expression defines a subpopulation of newborn DGCs with the highest probability of survival and incorporation into the pre-existing hippocampal circuit. The mechanisms connecting Arc expression to neurogenesis will thus be important to explore. Currently two candidate mechanisms stand out, depending on the age of the neurons. In undifferentiated cells, prior to synapse formation, Arc could act directly in the nucleus to promote proliferation, differentiation, and survival. As mentioned, Arc accumulates in the nucleus of hippocampal neurons where it localizes to PML bodies (Bloomer et al. 2007; Nair et al. 2009), dynamic and heterogeneous protein complexes, implicated in transcription, heterochromatin formation, and post-translational modifications (Wang et al. 1998; Zhong et al. 2000; Borden 2008) as well as cellular functions such as proliferation, apoptosis and senescence (Zhong et al. 2000; Bernardi and Pandolfi 2007; Sanchez-Pulido et al. 2007). In older DGCs forming excitatory synapses, NMDAR activation and LTP induction facilitates long-term survival (Bruel-Jungerman et al. 2006; Tashiro et al. 2007). At this later stage, Arc might promote survival by enabling stable LTP.

\section{Conclusions and future directions}

Arc transcription, RNA localization to activated synapses, and translation are all tightly coupled, with ERK playing a coordinating role in each of these events. Once translated, Arc RNA and protein are rapidly degraded. This has the makings of a specialized system for mediating adaptive changes in synaptic connectivity and behavior, in which the time, place, and amount of protein synthesis is critical.

Arc was originally identified as a cytoskeleton-associated protein. Bearing out this connection, recent studies link transient increases in Arc expression to stable expansion of the F-actin network in dendritic spines, which is believed to underlie morphological enlargement of the synapse and stable LTP. BDNF, a protein long implicated in synaptic plasticity and memory storage, activates Arcdependent consolidation and is necessary for actin-dependent spine enlargement. Current evidence further suggests a possible reciprocal interaction between F-actin formation, Arc, and translation during LTP consolidation (Fig. 3). The sequence of events in a working hypothesis are as follows:

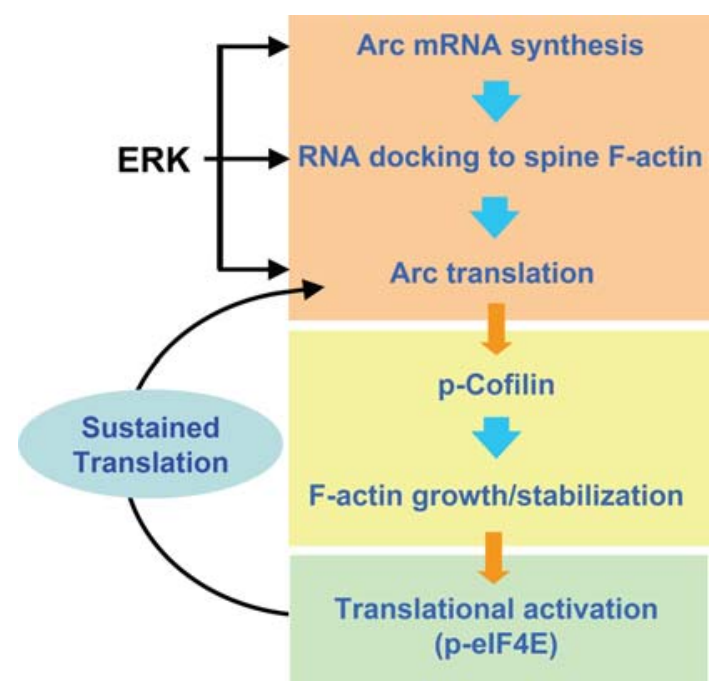

Fig. 3 Sequence of events in Arc-dependent LTP consolidation. This is a working hypothesis based mainly on studies of LTP in the medial perforant path input to granule cells of the rat dentate gyrus. Following LTP induction Arc mRNA is transported to dendrites where it localizes to the actin cytoskeleton within spines of activated synapses. Synaptically evoked ERK signaling coordinates Arc transcription, RNA docking, and translation. Arc synthesis within the spine is necessary for phosphorylation of cofilin and stable expansion of the F-actin network. In turn, regulation of actin dynamics by Arc is necessary for the maintenance of translation initiation factor eIF4E phosphorylation during LTP consolidation. Finally, phosphorylation of eIF4E, formation of the translation initiation complex, and Arc synthesis all require ERK signaling. Taken together, this has the makings of a positive feedback circuit which serves to sustain the local synthesis of Arc during the critical period of LTP consolidation. While not depicted here, it should be noted that BDNF is capable of activating Arc-dependent LTP consolidation. $B D N F$ brain-derived neurotrophic factor; $e I F 4 E$ eukaryotic initiation factor $4 \mathrm{E}$; $E R K$ extracellular signal-regulated kinase 
(1) immediate, protein synthesis-independent formation of F-actin in spines, (2) mRNA docking to spine F-actin, (3) Arc synthesis-dependent cofilin phosphorylation and F-actin stabilization, and (4) F-actin dependent facilitation of translation factor eIF4E phosphorylation. Such a positive feedback mechanism could serve to sustain Arc synthesis and cap-dependent translation in activated spines during LTP consolidation in the dentate gyrus (Fig. 3). However, there are numerous outstanding issues, including the mechanism by which Arc synthesis promotes cofilin phosphorylation.

Arc protein binds to components of the endocytic machinery, resulting in enhanced rates of AMPAR endocytosis and depression of excitatory synaptic transmission. This mechanism is activated during homeostatic plasticity and mechanistically distinct forms of LTD activated by group $1 \mathrm{mGluR}$ and NMDARs. One of the most exciting unresolved issues in the field is how Arc switches between regulation of the cytoskeleton and LTP, to regulation of endocytosis and LTD (Fig. 2). One factor appears to be the amount and kinetics of Arc protein expression. Thus, increases in Arc synthesis resulting from inhibition of natural nonsense-mediated RNA decay increases mEPSC amplitude, while expression of Arc transgene has the opposite effect. Studies employing Arc AS oligos and RNAi suggest that LTP consolidation and mGluR-dependent LTD are sensitive to acute modulation of activity-dependent protein synthesis, whereas more extreme changes in Arc levels obtained with transgenic overexpression or knockouts affect additional mechanisms such as NMDAR-dependent LTD. Post-translational modification of Arc or of one of its binding-partners represents another potential means for dictating the functional mode of Arc as synapses. Recent work showing a selective enrichment of SUMOylated Arc in the cytoskeletal fraction is intriguing in this regard (Nair et al. 2009; unpublished observations). By targeting Arc to the cytoskeleton, SUMOylation might favor Arc function in LTP consolidation. Whatever the mechanisms, current indications are that differential signaling through NMDAR, TrkB, and mGluR set the context for Arc function in LTP versus LTD.

Evidence for Arc synthesis in dendrites is compelling yet mostly circumstantial. Where does Arc travel from sites of synthesis in the dendrites and cell bodies? Does dendritically synthesized Arc selectively target spines undergoing LTP or LTD in the same neuron? What is the time course for these events? Novel approaches using time-lapse imaging are needed to address these fundamental issues. Ultimately, we need to know how this works in behaving animals. How are the various functions of Arc utilized to mediate adaptive and maladaptive changes of synaptic connectivity and behavior? Arc transcription has been correlated with learning experience and specific neuronal firing patterns, yet the synaptic regulation and function of Arc during learning remains unchartered ground. Once the molecular mechanisms that toggle Arc function are elucidated, it may be possible to devise reporter systems that visualize discrete sets of synapses undergoing potentiation and depression in living rodents.

Acknowledgments We acknowledge the Norwegian Research Council and the University of Bergen for financial support.

Open Access This article is distributed under the terms of the Creative Commons Attribution Noncommercial License which permits any noncommercial use, distribution, and reproduction in any medium, provided the original author(s) and source are credited.

\section{References}

Alder J, Thakker-Varia S, Bangasser DA, Kuroiwa M, Plummer MR, Shors TJ, Black IB (2003) Brain-derived neurotrophic factorinduced gene expression reveals novel actions of VGF in hippocampal synaptic plasticity. J Neurosci 23:10800-10808

Alme MN, Wibrand K, Dagestad G, Bramham CR (2007) Chronic fluoxetine treatment induces brain region-specific upregulation of genes associated with BDNF-induced long-term potentiation. Neural Plast 2007:26496

Antar LN, Afroz R, Dictenberg JB, Carroll RC, Bassell GJ (2004) Metabotropic glutamate receptor activation regulates fragile $x$ mental retardation protein and FMR1 mRNA localization differentially in dendrites and at synapses. J Neurosci 24:2648-2655

Bagni C, Mannucci L, Dotti CG, Amaldi F (2000) Chemical stimulation of synaptosomes modulates alpha $-\mathrm{Ca}^{2+} /$ calmodulindependent protein kinase II mRNA association to polysomes. J Neurosci 20(10):RC76

Banerjee PS, Aston J, Khundakar AA, Zetterstrom TS (2009) Differential regulation of psychostimulant-induced gene expression of brain derived neurotrophic factor and the immediate-early gene Arc in the juvenile and adult brain. Eur J Neurosci 29(3):465-476

Banko JL, Poulin F, Hou L, DeMaria CT, Sonenberg N, Klann E (2005) The translation repressor 4E-BP2 is critical for eIF4F complex formation, synaptic plasticity, and memory in the hippocampus. J Neurosci 25:9581-9590

Banko JL, Hou L, Poulin F, Sonenberg N, Klann E (2006) Regulation of eukaryotic initiation factor $4 \mathrm{E}$ by converging signaling pathways during metabotropic glutamate receptor-dependent long-term depression. J Neurosci 26:2167-2173

Belelovsky K, Elkobi A, Kaphzan H, Nairn AC, Rosenblum K (2005) A molecular switch for translational control in taste memory consolidation. Eur J Neurosci 22:2560-2568

Bernardi R, Pandolfi PP (2007) Structure, dynamics and functions of promyelocytic leukaemia nuclear bodies. Nat Rev Mol Cell Biol 8(12):1006-1016

Bliss T, Collingridge G, Morris R (2007) Synaptic plasticity in the hippocampus. In: Andersen P, Morris R, Amaral D, Bliss T, O'Keefe J (eds) The hippocampus book. Oxford University Press, pp 343-474

Bloomer WA, VanDongen HM, VanDongen AM (2007) Activityregulated cytoskeleton-associated protein Arc/Arg3.1 binds to spectrin and associates with nuclear promyelocytic leukemia (PML) bodies. Brain Res 1153:20-33

Bloomer WA, VanDongen HM, VanDongen AM (2008) Arc/Arg3.1 translation is controlled by convergent N-methyl-D-aspartate and Gs-coupled receptor signaling pathways. J Biol Chem 283(1):582-592 
Borden KL (2008) Pondering the puzzle of PML (promyelocytic leukemia) nuclear bodies: can we fit the pieces together using an RNA regulon? Biochim Biophys Acta 1783(11):2145-2154

Bourne JN, Harris KM (2008) Balancing structure and function at hippocampal dendritic spines. Annu Rev Neurosci 31:47-67

Bramham CR (2008) Local protein synthesis, actin dynamics, and LTP consolidation. Curr Opin Neurobiol 18(5):524-531

Bramham CR, Messaoudi E (2005) BDNF function in adult synaptic plasticity: the synaptic consolidation hypothesis. Prog Neurobiol 76:99-125

Bramham CR, Wells DG (2007) Dendritic mRNA: transport, translation and function. Nat Rev Neurosci 8(10):776-789

Bramham CR, Worley PF, Moore MJ, Guzowski JF (2008) The immediate early gene arc/arg3.1: regulation, mechanisms, and function. J Neurosci 28(46):11760-11767

Bruel-Jungerman E, Laroche S, Rampon C (2005) New neurons in the dentate gyrus are involved in the expression of enhanced longterm memory following environmental enrichment. Eur J Neurosci 21(2):513-521

Bruel-Jungerman E, Davis S, Rampon C, Laroche S (2006) Long-term potentiation enhances neurogenesis in the adult dentate gyrus. J Neurosci 26(22):5888-5893

Burke SN, Barnes CA (2008) Aging ensembles:circuit contributions to memory deficits. In: Mizumori SJY (ed) Hippocampal place fields: relevance to learning, memory. Oxford University Press, Oxford, pp 364-384

Cameron HA, McKay RD (2001) Adult neurogenesis produces a large pool of new granule cells in the dentate gyrus. J Comp Neurol 435:406-417

Cameron HA, Woolley CS, McEwen BS, Gould E (1993) Differentiation of newly born neurons and glia in the dentate gyrus of the adult rat. Neuroscience 56(2):337-344

Castillo PE, Francesconi A, Carroll RC (2008) The ups and downs of translation-dependent plasticity. Neuron 59(1):1-3

Castren E, Voikar V, Rantamaki T (2006) Role of neurotrophic factors in depression. Curr Opin Pharmacol 7(1):18-21

Chang YF, Chan WK, Imam JS, Wilkinson MF (2007) Alternatively spliced T-cell receptor transcripts are up-regulated in response to disruption of either splicing elements or reading frame. J Biol Chem 282(41):29738-29747

Chase T, Carrey N, Soo E, Wilkinson M (2007) Methylphenidate regulates activity regulated cytoskeletal associated but not brain-derived neurotrophic factor gene expression in the developing rat striatum. Neuroscience 144(3):969-984

Chotiner JK, Khorasani H, Nairn AC, O'Dell TJ, Watson JB (2003) Adenylyl cyclase-dependent form of chemical long-term potentiation triggers translational regulation at the elongation step. Neuroscience 116:743-752

Chowdhury S, Shepherd JD, Okuno H, Lyford G, Petralia RS, Plath N, Kuhl D, Huganir RL, Worley PF (2006) Arc/Arg3.1 interacts with the endocytic machinery to regulate AMPA receptor trafficking. Neuron 52(3):445-459

Citri A, Malenka RC (2008) Synaptic plasticity: multiple forms, functions, and mechanisms. Neuropsychopharmacology 33(1):18-41

Costa-Mattioli M, Sossin WS, Klann E, Sonenberg N (2009) Translational control of long-lasting synaptic plasticity and memory. Neuron 61(1):10-26

Dagestad G, Kuipers SD, Messaoudi E, Bramham CR (2006) Chronic fluoxetine induces region-specific changes in translation factor eIF4E and eEF2 activity in the rat brain. Eur J Neurosci 23:2814-2818

Davidovic L, Jaglin XH, Lepagnol-Bestel AM, Tremblay S, Simonneau M, Bardoni B, Khandjian EW (2007) The fragile X mental retardation protein is a molecular adaptor between the neurospecific KIF3C kinesin and dendritic RNA granules. Hum Mol Genet 16(24):3047-3058
Dayer AG, Ford AA, Cleaver KM, Yassaee M, Cameron HA (2003) Short-term and long-term survival of new neurons in the rat dentate gyrus. J Comp Neurol 460(4):563-572

Dictenberg JB, Swanger SA, Antar LN, Singer RH, Bassell GJ (2008) A direct role for FMRP in activity-dependent dendritic mRNA transport links filopodial-spine morphogenesis to fragile $\mathrm{X}$ syndrome. Dev Cell 14(6):926-939

Doetsch F, Hen R (2005) Young and excitable: the function of new neurons in the adult mammalian brain. Curr Opin Neurobiol 15(1):121-128

Donai H, Sugiura H, Ara D, Yoshimura Y, Yamagata K, Yamauchi T (2003) Interaction of Arc with CaM kinase II and stimulation of neurite extension by Arc in neuroblastoma cells expressing CaM kinase II. Neurosci Res 47:399-408

Dynes JL, Steward O (2007) Dynamics of bidirectional transport of Arc mRNA in neuronal dendrites. J Comp Neurol 500(3):433447

Farioli-Vecchioli S, Saraulli D, Costanzi M, Pacioni S, Cina I, Aceti M, Micheli L, Bacci A, Cestari V, Tirone F (2008) The timing of differentiation of adult hippocampal neurons is crucial for spatial memory. PLoS Biol 6(10):e246

Fletcher BR, Baxter MG, Guzowski JF, Shapiro ML, Rapp PR (2007) Selective cholinergic depletion of the hippocampus spares both behaviorally induced Arc transcription and spatial learning and memory. Hippocampus 17(3):227-234

Fukazawa Y, Saitoh Y, Ozawa F, Ohta Y, Mizuno K, Inokuchi K (2003) Hippocampal LTP is accompanied by enhanced F-actin content within the dendritic spine that is essential for late LTP maintenance in vivo. Neuron 38:447-460

Fumagalli F, Franchi C, Caffino L, Racagni G, Riva MA, Cervo L (2009) Single session of cocaine intravenous self-administration shapes goal-oriented behaviours and up-regulates Arc mRNA levels in rat medial prefrontal cortex. Int J Neuropsychopharmacol 12(3):423-429

Gao Y, Tatavarty V, Korza G, Levin MK, Carson JH (2008) Multiplexed dendritic targeting of alpha calcium calmodulindependent protein kinase II, neurogranin, and activity-regulated cytoskeleton-associated protein RNAs by the A2 pathway. Mol Biol Cell 19(5):2311-2327

Ge S, Yang CH, Hsu KS, Ming GL, Song H (2007) A critical period for enhanced synaptic plasticity in newly generated neurons of the adult brain. Neuron 54(4):559-566

Giorgi C, Yeo GW, Stone ME, Katz DB, Burge C, Turrigiano G, Moore MJ (2007) The EJC factor eIF4AIII modulates synaptic strength and neuronal protein expression. Cell 130(1):179-191

Gross SR, Kinzy TG (2007) Improper organization of the actin cytoskeleton affects protein synthesis at initiation. Mol Cell Biol 27(5): 1974-1989

Gusev PA, Cui C, Alkon DL, Gubin AN (2005) Topography of Arc/ Arg3.1 mRNA expression in the dorsal and ventral hippocampus induced by recent and remote spatial memory recall: dissociation of CA3 and CA1 activation. J Neurosci 25(41):9384-9397

Guzowski JF, Mcnaughton BL, Barnes CA, Worley PF (1999) Environment-specific expression of the immediate-early gene Arc in hippocampal neuronal ensembles. Nat Neurosci 2:1120-1124

Guzowski JF, Lyford GL, Stevenson GD, Houston FP, McGaugh JL, Worley PF, Barnes CA (2000) Inhibition of activity-dependent arc protein expression in the rat hippocampus impairs the maintenance of long-term potentiation and the consolidation of longterm memory. J Neurosci 20:3993-4001

Havik B, Rokke H, Bardsen K, Davanger S, Bramham CR (2003) Bursts of high-frequency stimulation trigger rapid delivery of preexisting alpha-CaMKII mRNA to synapses: a mechanism in dendritic protein synthesis during long-term potentiation in adult awake rats. Eur J Neurosci 17:2679-2689 
Havik B, Rokke H, Dagyte G, Stavrum AK, Bramham CR, Steen VM (2007) Synaptic activity-induced global gene expression patterns in the dentate gyrus of adult behaving rats: Induction of immunity-linked genes. Neuroscience 148(4):925-936

Huang F, Chotiner JK, Steward O (2007) Actin polymerization and ERK phosphorylation are required for Arc/Arg3.1 mRNA targeting to activated synaptic sites on dendrites. J Neurosci 27(34):9054-9067

Husi H, Ward MA, Choudhary JS, Blackstock WP, Grant SG (2000) Proteomic analysis of NMDA receptor-adhesion protein signaling complexes. Nat Neurosci 3:661-669

Hyman SE, Malenka RC, Nestler EJ (2006) Neural mechanisms of addiction: the role of reward-related learning and memory. Annu Rev Neurosci 29:565-598

Imayoshi I, Sakamoto M, Ohtsuka T, Takao K, Miyakawa T, Yamaguchi M, Mori K, Ikeda T, Itohara S, Kageyama R (2008) Roles of continuous neurogenesis in the structural and functional integrity of the adult forebrain. Nat Neurosci 11(10):1153-1161

Irie Y, Yamagata K, Gan Y, Miyamoto K, Do E, Kuo CH, Taira E, Miki N (2000) Molecular cloning and characterization of Amida, a novel protein which interacts with a neuron-specific immediate early gene product arc, contains novel nuclear localization signals, and causes cell death in cultured cells. J Biol Chem 275(4):2647-2653

Jessberger S, Kempermann G (2003) Adult-born hippocampal neurons mature into activity-dependent responsiveness. Eur J Neurosci 18(10):2707-2712

Kanai Y, Dohmae N, Hirokawa N (2004) Kinesin transports RNA: isolation and characterization of an RNA-transporting granule. Neuron 43:513-525

Kanhema T, Dagestad G, Panja D, Tiron A, Messaoudi E, Havik B, Ying SW, Nairn AC, Sonenberg N, Bramham CR (2006) Dual regulation of translation initiation and peptide chain elongation during BDNF-induced LTP in vivo: evidence for compartmentspecific translation control. J Neurochem 19:1328-1337

Kawashima T, Okuno H, Nonaka M, chi-Morishima A, Kyo N, Okamura M, Takemoto-Kimura S, Worley PF, Bito H (2009) Synaptic activity-responsive element in the Arc/Arg3.1 promoter essential for synapse-to-nucleus signaling in activated neurons. Proc Natl Acad Sci USA 106(1):316-321

Kee N, Teixeira CM, Wang AH, Frankland PW (2007) Preferential incorporation of adult-generated granule cells into spatial memory networks in the dentate gyrus. Nat Neurosci 10(3):355-362

Kelly MP, Deadwyler SA (2003) Experience-dependent regulation of the immediate-early gene arc differs across brain regions. J Neurosci 23:6443-6451

Kobayashi H, Yamamoto S, Maruo T, Murakami F (2005) Identification of a cis-acting element required for dendritic targeting of activity-regulated cytoskeleton-associated protein mRNA. Eur J Neurosci 22(12):2977-2984

Kozlovsky N, Matar MA, Kaplan Z, Kotler M, Zohar J, Cohen H (2008) The immediate early gene Arc is associated with behavioral resilience to stress exposure in an animal model of posttraumatic stress disorder. Eur Neuropsychopharmacol 18(2):107-116

Krishnan V, Nestler EJ (2008) The molecular neurobiology of depression. Nature 455(7215):894-902

Kubik S, Miyashita T, Guzowski JF (2007) Using immediate-early genes to map hippocampal subregional functions. Learn Mem 14(11):758-770

Kuipers SD, Tiron A, Soule J, Messaoudi E, Trentani A, Bramham CR (2009) Selective survival and maturation of adult-born dentate granule cells expressing the immediate early gene Arc/Arg3.1. PLoS One 4(3):e4885

Lacor PN, Buniel MC, Chang L, Fernandez SJ, Gong Y, Viola KL, Lambert MP, Velasco PT, Bigio EH, Finch CE, Krafft GA,
Klein WL (2004) Synaptic targeting by Alzheimer's-related amyloid beta oligomers. J Neurosci 24(45):10191-10200

Larsen MH, Rosenbrock H, Sams-Dodd F, Mikkelsen JD (2007) Expression of brain derived neurotrophic factor, activity-regulated cytoskeleton protein mRNA, and enhancement of adult hippocampal neurogenesis in rats after sub-chronic and chronic treatment with the triple monoamine re-uptake inhibitor tesofensine. Eur J Pharmacol 555(2-3):115-121

Lee PR, Cohen JE, Becker KG, Fields RD (2005) Gene expression in the conversion of early-phase to late-phase long-term potentiation. Ann N Y Acad Sci 1048:259-271

Leuner B, Gould E, Shors TJ (2006) Is there a link between adult neurogenesis and learning? Hippocampus 16(3):216-224

Li M, Hou YY, Lu B, Chen J, Chi ZQ, Liu JG (2009) Expression pattern of neural synaptic plasticity marker-Arc in different brain regions induced by conditioned drug withdrawal from acute morphine-dependent rats. Acta Pharmacol Sin 30(3):282-290

Liao L, Pilotte J, Xu T, Wong CC, Edelman GM, Vanderklish P, Yates JRIII (2007) BDNF induces widespread changes in synaptic protein content and up-regulates components of the translation machinery: an analysis using high-throughput proteomics. J Proteome Res 6(3):1059-1071

Link W, Konietzko U, Kauselmann G, Krug M, Schwanke B, Frey U, Kuhl D (1995) Somatodendritic expression of an immediate early gene is regulated by synaptic activity. Proc Natl Acad Sci USA 92:5734-5738

Lopez de HM, Jansen RP (2004) mRNA localization and the cytoskeleton. Curr Opin Cell Biol 16(1):80-85

Lucas M, Frenois F, Vouillac C, Stinus L, Cador M, Le MC (2008) Reactivity and plasticity in the amygdala nuclei during opiate withdrawal conditioning: differential expression of c-fos and arc immediate early genes. Neuroscience 154(3):1021-1033

Lyford GL, Yamagata K, Kaufmann WE, Barnes CA, Sanders LK, Copeland NG, Gilbert DJ, Jenkins NA, Lanahan AA, Worley PF (1995) Arc, a growth factor and activity-regulated gene, encodes a novel cytoskeleton-associated protein that is enriched in neuronal dendrites. Neuron 14:433-445

Lynch G, Rex CS, Gall CM (2007) LTP consolidation: substrates, explanatory power, and functional significance. Neuropharmacology $52(1): 12-23$

Maquat LE (2004) Nonsense-mediated mRNA decay: splicing, translation and mRNP dynamics. Nat Rev Mol Cell Biol 5(2):89-99

Matsuzaki M, Honkura N, Ellis-Davies GC, Kasai H (2004) Structural basis of long-term potentiation in single dendritic spines. Nature 429:761-766

McIntyre CK, Miyashita T, Setlow B, Marjon KD, Steward O, Guzowski JF, McGaugh JL (2005) Memory-influencing intra-basolateral amygdala drug infusions modulate expression of Arc protein in the hippocampus. Proc Natl Acad Sci USA 102(30):10718-10723

Messaoudi E, Ying SW, Kanhema T, Croll SD, Bramham CR (2002) Brain-derived neurotrophic factor triggers transcription-dependent, late phase long-term potentiation in vivo. J Neurosci 22:7453-7461

Messaoudi E, Kanhema T, Soule J, Tiron A, Dagyte G, da Silva B, Bramham CR (2007) Sustained Arc/Arg3.1 synthesis controls long-term potentiation consolidation through regulation of local actin polymerization in the dentate gyrus in vivo. $\mathrm{J}$ Neurosci 27(39):10445-10455

Meulmeester E, Melchior F (2008) Cell biology: SUMO. Nature 452(7188):709-711

Miyashita T, Kubik S, Haghighi N, Steward O, Guzowski JF (2009) Rapid activation of plasticity-associated gene transcription in hippocampal neurons provides a mechanism for encoding of onetrial experience. J Neurosci 29(4):898-906

Moga DE, Calhoun ME, Chowdhury A, Worley P, Morrison JH, Shapiro ML (2004) Activity-regulated cytoskeletal-associated 
protein is localized to recently activated excitatory synapses. Neuroscience 125:7-11

Molteni R, Calabrese F, Mancini M, Racagni G, Riva MA (2008) Basal and stress-induced modulation of activity-regulated cytoskeletal associated protein (Arc) in the rat brain following duloxetine treatment. Psychopharmacology Berl 201(2):285-292

Montag SM, Welzl H, Kuhl D, Montag D, Schachner M (1999) Novelty-induced increased expression of immediate-early genes c-fos and arg 3.1 in the mouse brain. J Neurobiol 38:234-246

Montag-Sallaz M, Montag D (2003) Learning-induced arg 3.1/arc mRNA expression in the mouse brain. Learn Mem 10(2):99-107

Morris RG (2006) Elements of a neurobiological theory of hippocampal function: the role of synaptic plasticity, synaptic tagging and schemas. Eur J Neurosci 23(11):2829-2846

Nair RR, Tiron A, Bramham CR (2009) SUMOylation-dependent subcellular localization of Arc/Arg3.1 in hippocampal neurons. Soc Neurosci Abstr 235.8

Nairn AC, Palfrey HC (1987) Identification of the major Mr 100, 000 substrate for calmodulin-dependent protein kinase III in mammalian cells as elongation factor-2. J Biol Chem 262:17299-17303

Narayanan U, Nalavadi V, Nakamoto M, Pallas DC, Ceman S, Bassell GJ, Warren ST (2007) FMRP phosphorylation reveals an immediate-early signaling pathway triggered by group I mGluR and mediated by PP2A. J Neurosci 27(52):14349-14357

Nelson SB, Turrigiano GG (2008) Strength through diversity. Neuron 60(3):477-482

Ni JZ, Grate L, Donohue JP, Preston C, Nobida N, O’Brien G, Shiue L, Clark TA, Blume JE, Ares M Jr (2007) Ultraconserved elements are associated with homeostatic control of splicing regulators by alternative splicing and nonsense-mediated decay. Genes Dev 21(6):708-718

Ostroff LE, Fiala JC, Allwardt B, Harris KM (2002) Polyribosomes redistribute from dendritic shafts into spines with enlarged synapses during LTP in developing rat hippocampal slices. Neuron 35:535-545

Overstreet-Wadiche LS, Westbrook GL (2006) Functional maturation of adult-generated granule cells. Hippocampus 16(3):208-215

Palop JJ, Chin J, Bien-Ly N, Massaro C, Yeung BZ, Yu GQ, Mucke L (2005) Vulnerability of dentate granule cells to disruption of arc expression in human amyloid precursor protein transgenic mice. J Neurosci 25(42):9686-9693

Pandey SC, Zhang H, Ugale R, Prakash A, Xu T, Misra K (2008) Effector immediate-early gene arc in the amygdala plays a critical role in alcoholism. J Neurosci 28(10):2589-2600

Panja D, Dagyte G, Bidinosti MT, Kristiansen AM, Sonenberg N, Bramham CR (2008) Translation control pathways underlying LTP maintenance in the dentate gyrus in vivo. Soc Neurosci Abstr 433.14

Park CS, Gong R, Stuart J, Tang SJ (2006) Molecular network and chromosomal clustering of genes involved in synaptic plasticity in the hippocampus. J Biol Chem 281(40):30195-30211

Park S, Park JM, Kim S, Kim JA, Shepherd JD, Smith-Hicks CL, Chowdhury S, Kaufmann W, Kuhl D, Ryazanov AG, Huganir RL, Linden DJ, Worley PF (2008) Elongation factor 2 and fragile $\mathrm{X}$ mental retardation protein control the dynamic translation of Arc/Arg3.1 essential for mGluR-LTD. Neuron 59(1):70-83

Pastalkova E, Serrano P, Pinkhasova D, Wallace E, Fenton AA, Sacktor TC (2006) Storage of spatial information by the maintenance mechanism of LTP. Science 313(5790):1141-1144

Peebles CL, Finkbeiner S (2007) RNA decay back in play. Nat Neurosci 10(9):1083-1084

Pei Q, Zetterstrom TS, Sprakes M, Tordera R, Sharp T (2003) Antidepressant drug treatment induces Arc gene expression in the rat brain. Neuroscience 121:975-982

Pintchovski SA, Peebles CL, Kim HJ, Verdin E, Finkbeiner S (2009) The serum response factor and a putative novel transcription factor regulate expression of the immediate-early gene Arc/ Arg3.1 in neurons. J Neurosci 29(5):1525-1537

Plath N, Ohana O, Dammermann B, Errington ML, Schmitz D, Gross C, Mao X, Engelsberg A, Mahlke C, Welzl H, Kobalz U, Stawrakakis A, Fernandez E, Waltereit R, Bick-Sander A, Therstappen E, Cooke SF, Blanquet V, Wurst W, Salmen B, Bosl MR, Lipp HP, Grant SG, Bliss TV, Wolfer DP, Kuhl D (2006) Arc/Arg3.1 is essential for the consolidation of synaptic plasticity and memories. Neuron 52(3):437-444

Ploski JE, Pierre VJ, Smucny J, Park K, Monsey, Overeem KA, Schafe GE (2008) The activity-regulated cytoskeletal-associated protein (Arc/Arg3.1) is required for memory consolidation of pavlovian fear conditioning in the lateral amygdala. $J$ Neurosci 28(47):12383-12395

Proud CG (2007) Signalling to translation: how signal transduction pathways control the protein synthetic machinery. Biochem $\mathrm{J}$ 403(2):217-234

Ramirez-Amaya V, Marrone DF, Gage FH, Worley PF, Barnes CA (2006) Integration of new neurons into functional neural networks. J Neurosci 26(47):12237-12241

Rao VR, Pintchovski SA, Chin J, Peebles CL, Mitra S, Finkbeiner S (2006) AMPA receptors regulate transcription of the plasticity-related immediate-early gene Arc. Nat Neurosci 9(7):887-895

Rial Verde EM, Lee-Osbourne J, Worley PF, Malinow R, Cline HT (2006) Increased expression of the immediate-early gene arc/ arg3.1 reduces AMPA receptor-mediated synaptic transmission. Neuron 52(3):461-474

Richter JD, Sonenberg N (2005) Regulation of cap-dependent translation by eIF4E inhibitory proteins. Nature 433:477-480

Rodriguez JJ, Davies HA, Silva AT, De Souza IE, Peddie CJ, Colyer FM, Lancashire CL, Fine A, Errington ML, Bliss TV, Stewart MG (2005) Long-term potentiation in the rat dentate gyrus is associated with enhanced Arc/Arg3.1 protein expression in spines, dendrites and glia. Eur J Neurosci 21:2384-2396

Rook MS, Lu M, Kosik KS (2000) CaMKIIalpha 3' untranslated region-directed mRNA translocation in living neurons: visualization by GFP linkage. J Neurosci 20:6385-6393

Ryazanov AG, Shestakova EA, Natapov PG (1988) Phosphorylation of elongation factor 2 by EF-2 kinase affects rate of translation. Nature 334:170-173

Sanchez-Pulido L, Valencia A, Rojas AM (2007) Are promyelocytic leukaemia protein nuclear bodies a scaffold for caspase-2 programmed cell death? Trends Biochem Sci 32(9):400-406

Scheetz AJ, Nairn AC, Constantine-Paton M (2000) NMDA receptormediated control of protein synthesis at developing synapses. Nat Neurosci 3:211-216

Schmidt-Hieber C, Jonas P, Bischofberger J (2004) Enhanced synaptic plasticity in newly generated granule cells of the adult hippocampus. Nature 429(6988): 184-187

Shepherd JD, Rumbaugh G, Wu J, Chowdhury S, Plath N, Kuhl D, Huganir RL, Worley PF (2006) Arc/Arg3.1 mediates homeostatic synaptic scaling of AMPA receptors. Neuron 52(3):475-484

Shors TJ, Miesegaes G, Beylin A, Zhao M, Rydel T, Gould E (2001) Neurogenesis in the adult is involved in the formation of trace memories. Nature 410(6826):372-376

Small SA, Chawla MK, Buonocore M, Rapp PR, Barnes CA (2004) Imaging correlates of brain function in monkeys and rats isolates a hippocampal subregion differentially vulnerable to aging. Proc Natl Acad Sci USA 101(18):7181-7186

Smart FM, Edelman GM, Vanderklish PW (2003) BDNF induces translocation of initiation factor 4E to mRNA granules: evidence for a role of synaptic microfilaments and integrins. Proc Natl Acad Sci USA 100:14403-14408

Sonenberg N, Hinnebusch AG (2009) Regulation of translation initiation in eukaryotes: mechanisms and biological targets. Cell 136(4):731-745 
Soule J, Penke Z, Kanhema T, Alme MN, Laroche S, Bramham CR (2008) Object-place recognition learning triggers rapid induction of plasticity-related immediate early genes and synaptic proteins in the rat dentate gyrus. Neural Plast 2008:269097

Steward O, Levy WB (1982) Preferential localization of polyribosomes under the base of dendritic spines in granule cells of the dentate gyrus. J Neurosci 2:284-291

Steward O, Reeves TM (1988) Protein-synthetic machinery beneath postsynaptic sites on CNS neurons: association between polyribosomes and other organelles at the synaptic site. J Neurosci 8:176-184

Steward O, Schuman EM (2003) Compartmentalized synthesis and degradation of proteins in neurons. Neuron 40:347-359

Steward O, Worley PF (2001) Selective targeting of newly synthesized Arc mRNA to active synapses requires NMDA receptor activation. Neuron 30:227-240

Steward O, Wallace CS, Lyford GL, Worley PF (1998) Synaptic activation causes the mRNA for the IEG Arc to localize selectively near activated postsynaptic sites on dendrites. Neuron 21(4):741-751

Sutton MA, Taylor AM, Ito HT, Pham A, Schuman EM (2007) Postsynaptic decoding of neural activity: eEF2 as a biochemical sensor coupling miniature synaptic transmission to local protein synthesis. Neuron 55(4):648-661

Tanaka J, Horiike Y, Matsuzaki M, Miyazaki T, Ellis-Davies GC, Kasai H (2008) Protein synthesis and neurotrophin-dependent structural plasticity of single dendritic spines. Science 319(5870):1683-1687

Tashiro A, Makino H, Gage FH (2007) Experience-specific functional modification of the dentate gyrus through adult neurogenesis: a critical period during an immature stage. J Neurosci 27(12):3252-3259

Teber I, Kohling R, Speckmann EJ, Barnekow A, Kremerskothen J (2004) Muscarinic acetylcholine receptor stimulation induces expression of the activity-regulated cytoskeleton-associated gene (ARC). Brain Res Mol Brain Res 121(1-2):131-136

Tiron A, Bramham CR (2008) Arc/Arg3.1 dynamically regulates translation factor activity during LTP maintenance in the adult rat brain in vivo. Soc Neurosci Abstr 433.15

Toni N, Teng EM, Bushong EA, Aimone JB, Zhao C, Consiglio A, van PH, Martone ME, Ellisman MH, Gage FH (2007) Synapse formation on neurons born in the adult hippocampus. Nat Neurosci 10(6):727-734

Turrigiano GG (2008) The self-tuning neuron: synaptic scaling of excitatory synapses. Cell 135(3):422-435

Tzingounis AV, Nicoll RA (2006) Arc/Arg3.1: linking gene expression to synaptic plasticity and memory. Neuron 52(3):403-407

Vazdarjanova A, Guzowski JF (2004) Differences in hippocampal neuronal population responses to modifications of an environmental context: evidence for distinct, yet complementary, functions of $\mathrm{CA} 3$ and $\mathrm{CA} 1$ ensembles. J Neurosci 24(29):6489-6496

Vazdarjanova A, McNaughton BL, Barnes CA, Worley PF, Guzowski JF (2002) Experience-dependent coincident expression of the effector immediate-early genes arc and Homer 1a in hippocampal and neocortical neuronal networks. J Neurosci 22(23):1006710071

Viola KL, Velasco PT, Klein WL (2008) Why Alzheimer's is a disease of memory: the attack on synapses by A beta oligomers (ADDLs). J Nutr Health Aging 12(1):51S-57S

Walden WE, Thach RE (1986) Translational control of gene expression in a normal fibroblast. Characterization of a subclass of mRNAs with unusual kinetic properties. Biochemistry 25(8):2033-2041
Wallace CS, Lyford GL, Worley PF, Steward O (1998) Differential intracellular sorting of immediate early gene mRNAs depends on signals in the mRNA sequence. J Neurosci 18:26-35

Waltereit R, Dammermann B, Wulff P, Scafidi J, Staubli U, Kauselmann G, Bundman M, Kuhl D (2001) Arg3.1/Arc mRNA induction by $\mathrm{Ca} 2+$ and cAMP requires protein kinase $\mathrm{A}$ and mitogen-activated protein kinase/extracellular regulated kinase activation. J Neurosci 21:5484-5493

Wang ZG, Ruggero D, Ronchetti S, Zhong S, Gaboli M, Rivi R, Pandolfi PP (1998) PML is essential for multiple apoptotic pathways. Nat Genet 20(3):266-272

Wang HW, Pasternak JF, Kuo H, Ristic H, Lambert MP, Chromy B, Viola KL, Klein WL, Stine WB, Krafft GA, Trommer BL (2002) Soluble oligomers of beta amyloid (1-42) inhibit long-term potentiation but not long-term depression in rat dentate gyrus. Brain Res 924(2):133-140

Wang DC, Chen SS, Lee YC, Chen TJ (2006) Amyloid-beta at sublethal level impairs BDNF-induced arc expression in cortical neurons. Neurosci Lett 398:78-82

Wang Y, Zheng F, Zhou X, Sun Z, Wang H (2009) Converging signal on ERK1/2 activity regulates group I mGluR-mediated Arc transcription. Neurosci Lett 460(1):36-40

Waung MW, Pfeiffer BE, Nosyreva ED, Ronesi JA, Huber KM (2008) Rapid translation of Arc/Arg3.1 selectively mediates mGluRdependent LTD through persistent increases in AMPAR endocytosis rate. Neuron 59(1):84-97

Wibrand K, Messaoudi E, Havik B, Steenslid V, Lovlie R, Steen VM, Bramham CR (2006) Identification of genes co-upregulated with Arc during BDNF-induced long-term potentiation in adult rat dentate gyrus in vivo. Eur J Neurosci 23(6):1501-1511

Wittmann J, Hol EM, Jack HM (2006) hUPF2 silencing identifies physiologic substrates of mammalian nonsense-mediated mRNA decay. Mol Cell Biol 26(4):1272-1287

Yasuda M, Fukuchi M, Tabuchi A, Kawahara M, Tsuneki H, Azuma Y, Chiba Y, Tsuda M (2007) Robust stimulation of TrkB induces delayed increases in BDNF and Arc mRNA expressions in cultured rat cortical neurons via distinct mechanisms. J Neurochem 103(2):626-636

Yin Y, Edelman GM, Vanderklish PW (2002) The brain-derived neurotrophic factor enhances synthesis of Arc in synaptoneurosomes. Proc Natl Acad Sci USA 99:2368-2373

Ying SW, Futter M, Rosenblum K, Webber MJ, Hunt SP, Bliss TV, Bramham CR (2002) Brain-derived neurotrophic factor induces long-term potentiation in intact adult hippocampus: requirement for ERK activation coupled to CREB and upregulation of Arc synthesis. J Neurosci 22:1532-1540

Yoshimura A, Fujii R, Watanabe Y, Okabe S, Fukui K, Takumi T (2006) Myosin-Va facilitates the accumulation of mRNA/protein complex in dendritic spines. Curr Biol 16(23):2345-2351

Zalfa F, Giorgi M, Primerano B, Moro A, Di Penta A, Reis S, Oostra $\mathrm{B}$, Bagni C (2003) The fragile X syndrome protein FMRP associates with $\mathrm{BC} 1 \mathrm{RNA}$ and regulates the translation of specific $\mathrm{mR}$ NAs at synapses. Cell 112:317-327

Zhang CL, Zou Y, He W, Gage FH, Evans RM (2008) A role for adult TLX-positive neural stem cells in learning and behaviour. Nature 451(7181): 1004-1007

Zhao C, Teng EM, Summers RG Jr, Ming GL, Gage FH (2006) Distinct morphological stages of dentate granule neuron maturation in the adult mouse hippocampus. J Neurosci 26(1):3-11

Zhao C, Deng W, Gage FH (2008) Mechanisms and functional implications of adult neurogenesis. Cell 132(4):645-660

Zhong S, Salomoni P, Pandolfi PP (2000) The transcriptional role of PML and the nuclear body. Nat Cell Biol 2(5):E85-E90 